\title{
Influence of Amniotic Fluid Volume on Lecithin Estimation in Prediction of Respiratory Distress
}

\author{
G. F. FALCONER, J. S. HODGE， R. L. GADD
}

British Medical fournal, 1973, 2, 689-691

\section{Summary}

One hundred samples of amniotic fluid were obtained by amniocentesis from 82 patients at different stages of normal and abnormal pregnancies. The concentration of lecithin was estimated together with the volume of the amniotic fluid, using the dilution technique. Thus the total quantity of lecithin in any amniotic sac could be calculated. While confirming the findings of others that concentrations of lecithin below $3.5 \mathrm{mg} / 100 \mathrm{ml}$ in the liquor immediately before delivery suggested that the baby was likely to develop respiratory distress syndrome, we found that in borderline cases the total amount of lecithin in the sac was of greater prognostic significance than the lecithin concentration.

\section{Introduction}

Respiratory function in the newborn is now known to depend on the intrauterine development of adequate amounts of surfactant within the epithelial cells of the alveoli (Adams et al., 1965; Brumley et al., 1967). Since fluid passes from the fetal respiratory tract to the amniotic cavity carrying with it suspended surfactant from the alveoli (Biggs et al., 1973) the concentration in fetal lung tissue should be reflected in the surfactant content of the amniotic fluid (Nelson, 1970).

Gluck et al. (1971) accumulated convincing evidence to support this concept by analysing phospholipids in the amniotic fluid and they believe that fetal lungs are mature and the infants free from risk of respiratory distress when the lecithin/sphingomyelin ratio is $2: 1$ or greater. By using a ratio they possibly avoided variations which may occur in the lecithin concentration with changing liquor volumes. Evidence now suggests that the sphingomyelin has a different origin than the surface-active lecithin (Biggs, 1973).

Bhagwanani et al. found that the concentration of lecithin in the amniotic fluid seemed to give an accurate forecast of respiratory difficulty in the neonate. They found this more reliable than the lecithin/sphingomyelin ratio because the end point of the determination was more precise. They gave a critical level of $3.5 \mathrm{mg} / 100 \mathrm{ml}$. They further added that the main theoretical disadvantage of measuring the lecithin concentration was that excessively large or small amounts of liquor might produce misleading results. In their experience, however, the prognostic reliability of the liquor lecithin concentration had not been significantly affected by large or small volumes of amniotic fluid.

We decided to estimate liquor volumes in all patients on whom lecithin estimations were requested and thereby calculate

\footnotetext{
Department of Obstetrics and Gynaecology, St. Mary's Hospital, Manchester M13 0JH

G. F. FALCONER, M.R.c.s., M.R.C.o.G., Registrar in Obstetrics and Gynaecology (Present appointment: Senior Registrar in Obstetrics and Gynaecology, Hope Hospital, Salford, Manchester)

I. S. HODGE, PH.D., Senior Biochemist

R. L. GADD, M.D., F.R.C.o.G., Consultant Obstetrician and Gynaecologist
}

the total lecithin present in the amniotic sac. In this way we would be able to determine whether the estimation of total lecithin would facilitate our management of borderline "at risk" cases.

\section{Material and Methods}

One hundred samples of amniotic fluid were obtained from 82 patients by amniocentesis. Fifteen samples were from diabetics, 16 from patients with pre-eclamptic toxaemia, 12 from patients with rhesus isoimmunization, eight from patients before elective caesarean section, five from mothers with clinically small-for-dates babies, and the remaining 26 from mothers who were uncertain of their menstrual history. In the last group fetal maturity was assessed independently at birth by a paediatrician. All samples contaminated with meconium or blood were discarded.

The liquor volume was estimated by the dilution method using sodium aminohippurate (Charles and Jacoby, 1966). All the amniocenteses were carried out by one of us (G.F.F.). There was no maternal or fetal morbidity. The liquor lipid was extracted according to the method of Bligh and Dyer (1959) and the individual phospholipids were separated by thin layer chromatography on silica gel (Skipski et al., 1963). Lecithin was measured quantitatively by the determination of phosphorous (Bartlett, 1959) in the appropriate areas of silica gel. Results were expressed as dipalmitoyl lecithin.

The babies' respiratory states.were assessed by a paediatrician who had no foreknowledge of the liquor lecithin concentrations.

\section{Results}

The mean lecithin concentration in the 100 amniotic fluid samples obtained from 82 normal and abnormal pregnancies (fig. 1) showed a similar pattern to the results of Bhagwanani et al. (1972) obtained from 90 normal pregnancies (fig. 2). From mean liquor volumes of the 100 cases examined (fig. 3) it was found that the liquor volume increased with age up to 34-36 weeks, then reached a plateau, and finally fell as term approached. The results were similar to those previously found (Gadd, 1966). However, there were considerable variations within the mean which might have affected the lecithin concentration in a specific case.

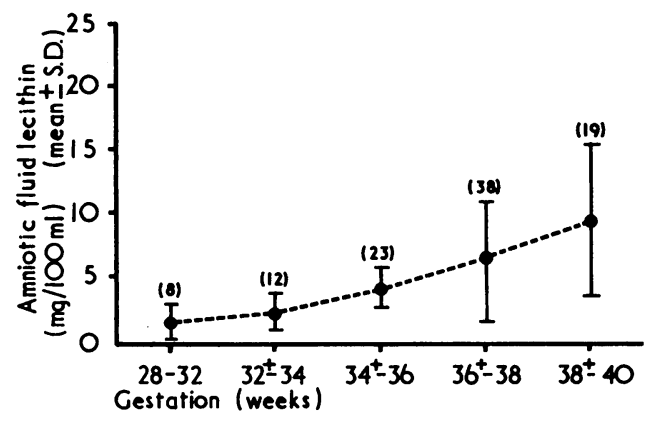

FIG. 1-Mean \pm S.D. amniotic fluid lecithin concentration in normal and abnormal pregnancies. Number of samples in each group is shown in parentheses. 


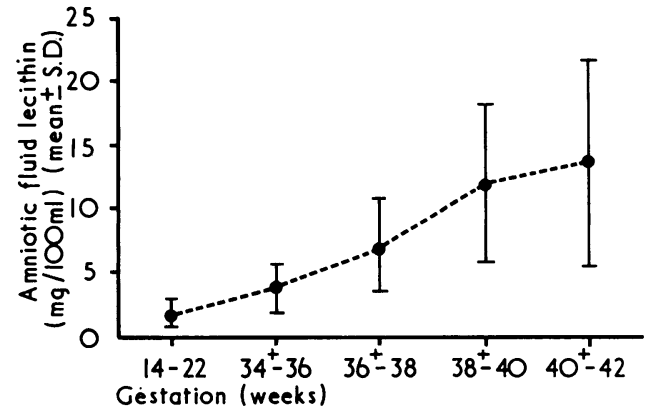

FIG. 2-Mean + S.D. amniotic fluid lecithin in normal pregnancies. (Taken from Bhagwanani et al. (1972).)

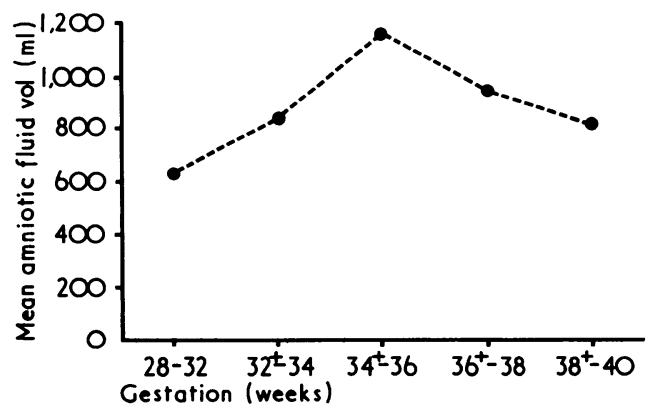

FIG. 3-Mean amniotic volume in the 100 cases examined.

The mean total lecithin in the amniotic sac in the same 100 cases (fig. 4) showed a rise from 28 to 36 weeks, a slight fall from 36 to 38 weeks, and then a rapid rise until term. The lecithin concentrations shown in fig. 5 were plotted against total amounts of lecithin per sac. It can be seen that around the critical concentration of $3.5 \mathrm{mg} / 100 \mathrm{ml}$ the total lecithin varied between 18 and $55 \mathrm{mg}$.

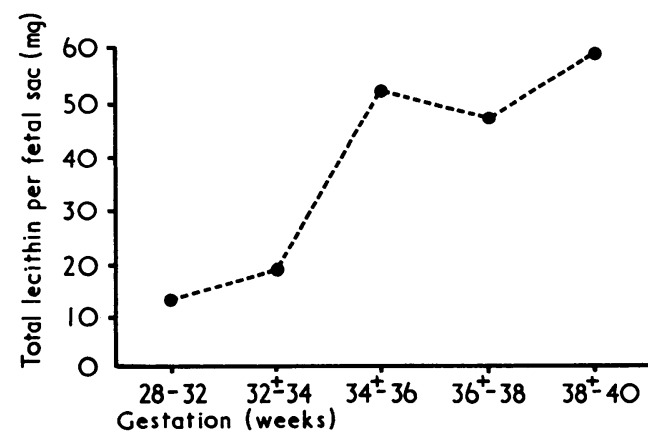

FIG. 4-Mean total lecithin in amniotic sac.

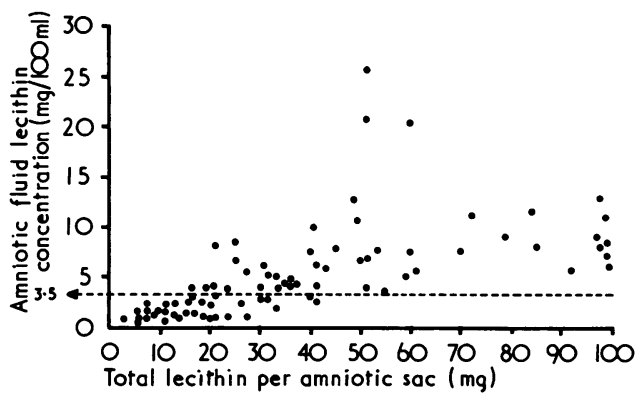

FIG. 5-Total lecithin per amniotic sac plotted against lecithin concentration in 83 cases. (Remainder had totals outside range of graph.)

The neonatal respiratory function in six consecutive cases with critical predelivery concentrations of lecithin estimated within 24 hours before delivery is shown in the table. Case 3 is of interest. From the low concentration of lecithin $(1.9 \mathrm{mg} / 100 \mathrm{ml})$ some degree of respiratory distress would be expected, but the baby's respiratory function was normal. The volume of amniotic fluid was large, however, and the total amount of lecithin was much higher than that in cases 1,4 , and 5 , which in themselves had a higher concentration. Case 4 , did in fact develop mild, transient respiratory distress and case 5 moderate respiratory distress.

In 26 patients in this series who required induction of labour for various reasons the liquor lecithin concentration was found to be above $4 \mathrm{mg} / 100 \mathrm{ml}$. Respiratory distress did not occur in any of these cases. In eight patients induction was delayed for four days or more because the lecithin was low (below $4 \mathrm{mg}$ / $100 \mathrm{ml}$ ) and it was thought to be safe to wait. The elective caesarean sections were delayed one week because the predelivery lecithin concentrations were low.

\section{Discussion}

These preliminary findings support those of Bhagwanani et al., who suggested that the mean levels of lecithin concentration from abnormal cases of rhesus disease, pre-eclampsia, and placental insufficiency obtained at various stages of gestation showed no significant difference when compared with normal levels.

The plateau that occurs between $36-38$ weeks when measuring total lecithin per sac is difficult to interpret. It differs from the steady rise that is seen when lecithin concentration alone is measured (fig. 1). It may, however, be due to the fact that the amniotic fluid volume begins to fall off at 36-38 weeks and in measuring concentration alone there is an apparent rise in lecithin, but there is not in fact a rise in total amount until the "surge" of the second lecithin pathway appears (Gluck et al.,

Neonatal Respiratory Function in 6 Cases with Critical Predelivery Amniotic Fluid Lecithin Concentration (1.9-4.0 mg/100 ml)

\begin{tabular}{|c|c|c|c|c|c|c|c|c|c|c|}
\hline $\begin{array}{l}\text { Case } \\
\text { No. }\end{array}$ & Sex & $\begin{array}{l}\text { Week of } \\
\text { Gestation }\end{array}$ & $\begin{array}{l}\text { Birth } \\
\text { Weight } \\
\text { (g) }\end{array}$ & $\begin{array}{c}\text { Birth } \\
\text { Weight } \\
\text { Percentile }\end{array}$ & Nature of Delivery & $\begin{array}{c}\text { Amniotic } \\
\text { Fluid } \\
\text { Volume } \\
\text { (ml) }\end{array}$ & $\left|\begin{array}{c}\text { Concen- } \\
\text { tration } \\
(\mathbf{m g} / \mathbf{1 0 0 m l})\end{array}\right|$ & $\begin{array}{l}\text { Lecithin } \\
\text { Total } \\
\text { (mg) }\end{array}$ & Respiratory Function & Remarks \\
\hline $\begin{array}{l}1 \\
2\end{array}$ & $\begin{array}{l}\mathbf{F} \\
\mathbf{M}\end{array}$ & $\begin{array}{l}37 \\
37\end{array}$ & $\begin{array}{l}2,300 \\
3,220\end{array}$ & $\begin{array}{l}10 \\
\text { Just } \\
\text { below } 75\end{array}$ & $\begin{array}{l}\text { Induced normal delivery } \\
\text { Elective L.S.C.S. }\end{array}$ & $\begin{array}{r}525 \\
1,143\end{array}$ & $\begin{array}{l}4 \cdot 0 \\
3 \cdot 4\end{array}$ & $\begin{array}{l}21 \cdot 0 \\
38 \cdot 9\end{array}$ & $\begin{array}{l}\text { Normal } \\
\text { Normal }\end{array}$ & $\begin{array}{l}\text { Pre-eclamptic toxaemia } \\
\text { Renal Glycosuria, } \\
\text { previous stillbirth }\end{array}$ \\
\hline 3 & F. & 36 & 3,220 & $\begin{array}{l}\text { Just } \\
\text { above } 75\end{array}$ & Emergency L.S.C.S. & 1,760 & 1.9 & $33 \cdot 0$ & Normal & $\begin{array}{l}\text { Recurrent antepartum } \\
\text { haemorrhages, } \\
\text { placenta praevia }\end{array}$ \\
\hline $\begin{array}{l}4 \\
5\end{array}$ & $\begin{array}{l}\text { F. } \\
\text { F. }\end{array}$ & $\begin{array}{l}32 \\
37\end{array}$ & $\begin{array}{l}2,240 \\
1,980\end{array}$ & $\begin{array}{l}75 \\
\text { Below } \\
10\end{array}$ & $\begin{array}{l}\text { Induced normal delivery } \\
\text { Induced emergency L.S.C.S. }\end{array}$ & $\begin{array}{l}602 \\
507\end{array}$ & $\begin{array}{l}3.5 \\
3.9\end{array}$ & $\begin{array}{l}20 \cdot 8 \\
19 \cdot 8\end{array}$ & $\begin{array}{l}\text { Transient R.D.S. } \\
\text { Mod./severe R.D.S. }\end{array}$ & $\begin{array}{l}\text { Severe rhesus disease } \\
\text { Small for dates, } \\
\text { fulminate pre- }\end{array}$ \\
\hline 6 & F. & 37 & 2,820 & $25-50$ & Induced forceps & 857 & $4 \cdot 0$ & $34 \cdot 3$ & Normal & $\begin{array}{l}\text { eclamptac toxaemia } \\
\text { Pre-eclamptic } \\
\text { toxaemia }\end{array}$ \\
\hline
\end{tabular}

L.S.C.S. = Lower segment caesarean section.

R.D.S. = Respiratory distress syndrome. 
1972). Further studies, particularly serial totals in individual patients, should clarify this point.

In patients who are uncertain of their menstrual dates and in whom postmaturity may be feared we have preferred to assess the pulmonary maturity by lecithin estimations in preference to other methods of estimating fetal gestation. Though liquor volume, and hence total lecithin content per fetal sac, seems to be unimportant to the prognostic reliability of lecithin concentration in most cases, the evidence suggests that it is important in borderline cases where the lecithin concentration is around $3.5 \mathrm{ml} / 100 \mathrm{ml}$ and a decision has to be made on whether to deliver. If total lecithin in the sac is to be used as the parameter it would seem from our preliminary series that levels below $20 \mathrm{mg}$ per sac indicate that the fetus would be at risk if delivered.

We wish to thank the consultant obstetricians at Saint Mary's Hospital for access to their patients and also to thank the consultant paediatricians for their help in assessing neonatal maturity.

\section{References}

Adams, F. H., Fujiwara, T., Emmanouilides, G., and Scudder, A. (1965). Fournal of Pediatrics, 66, 357.

Bartlett, G. R. (1959). Fournal of Biological Chemistry, 234, 466.

Bhagwanani, S. G., Fahmy, D., and Turnbull, A. C. (1972). Lancet, 1, 159, 160.

Biggs, J. S. G., Gaffney, T. J., and McGeary, H. M. (1973). Fournal of Obstetrics and Gynaecology of the British Commonwealth, 80, 125.

Bligh, E. G., and Dyer, W. J. (1959). Canadian fournal of Biochemistry and Physiology, 37, 911 .

Brumley, G. W., Hodson, W. A., and Avery, M. E. (1967). Pediatrics, 40, 13.

Charles, D., and Jacoby, H. E. (1966). American fournal of Obstetrics and Gynecology, 95, 266.

Gadd, R. L. (1966). Fournal of Obstetrics and Gynaecology of the British Commonwealth, 73, 11.

Gluck, L., et al. (1971). American fournal of Obstetrics and Gynecology, 109, 440.

Gluck, L., Kulovich, M. V., Eidelman, A. I., Cordero, L., and Khazin, A. F. (1972). Pediatric Research, 6, 81.

Nelson, G. H. (1970). American fournal of Obstetrics and Gynecology, 105, 1072 .

Skipski, V. P., Peterson, R. F., Sanders, J., and Barclay, M. (1963). fournal of Lipid Research, 4, 227.

\title{
Effect of Different Periods of Fasting on Oral Glucose Tolerance
}

\author{
C. H. WALSH, J. O'REGAN, D. J O'SULLIVAN
}

British Medical Fournal, 1973, 2, 691-693

\section{Summary}

The effect of different periods of fasting on oral glucose tolerance was investigated in 33 subjects. It was found that glucose tolerance deteriorated as the fasting period became shorter. This effect was seen almost exclusively in subjects over 40 years of age. Only the fasting blood sugar was affected by the duration of the pretest fast in younger subjects.

\section{Introduction}

The oral glucose tolerance test was introduced by Hamman and Hirschman (1917), after some preliminary work by Jacobsen (1913) and Hopkins (1915). Though its value in the definitive diagnosis of diabetes mellitus is unchallenged, it has in recent years been under close and critical scrutiny (McDonald et al., 1965; Klimt et al., 1969). It is only to be expected, however, that years of use should expose some of its shortcomings. These have recently been comprehensively reviewed by the Committee on Statistics of the American Diabetes Association (Klimt et al., 1969). Any study that will help to reduce the multiplicity of variables associated with the test is likely to be of much value. Little information and considerable difference of opinion exist about the significance of the length of the pretest fasting period. Because of this we have undertaken a study of the influence of various periods of fasting on glucose tolerance.

Department of Medicine, St. Finbarr's Hospital, Cork, and University College, Cork, Eire

C. H. WALSH, M.B., M.R.C.P., Medical Registrar (Present address: General Hospital, Birmingham)

J. O'REGAN, M.B., B.A.O., Senior House Office

D. J. O'SULLIVAN, M.D., F.R.C.P., Professor of Medicine

\section{Subjects and Methods}

Thirty-three subjects were investigated, 17 men and 16 women. Their ages ranged from 18 to 84 years (mean age 46 years). They comprised medical students and staff from the department of medicine together with long-stay occupants of an institution for the homeless. Several of the latter were employed in domestic duties. All subjects were clinically healthy and ambulant, apart from one who had suffered a cerebrovascular accident several years previously.

All were on an unrestricted diet and none was on any agents known to interfere with glucose tolerance. Each subject had three glucose tolerance tests $(50 \mathrm{~g}$ glucose) within a period of two weeks. Before each test they fasted for 12 , eight, or four hours in random fashion. The last meal was taken immediately before the start of the fasting period, and was constant in composition, containing about $30 \mathrm{~g}$ carbohydrate in tea, bread, butter, and jam. The tests were carried out under strictly standardized conditions and all began between 0900 and 0930 hours.

\section{Results}

The results for the 33 subjects are given in table I and fig. 1 .

TABLE I-Mean ( \pm S.D. of Mean) Blood Sugar Values $(\mathrm{mg} / 100 \mathrm{ml})$ for Three Glucose Tolerance Tests in 33 Subjects

\begin{tabular}{|c|c|c|c|c|c|c|c|}
\hline \multirow{2}{*}{\multicolumn{2}{|c|}{ Pretest Fast }} & & \multicolumn{5}{|c|}{ Time (Minutes) } \\
\hline & & & 0 & 30 & 60 & 90 & 120 \\
\hline $\begin{array}{r}12 \text { hours } \\
8 \text { hours } \\
4 \text { hours }\end{array}$ & & $\begin{array}{l}. \\
\cdots\end{array}$ & $\begin{array}{l}73 \pm 9 \\
81 \pm 12 \\
77 \pm 12\end{array}$ & $\begin{array}{l}108 \pm 21 \\
118 \pm 29 \\
124 \pm 31\end{array}$ & $\begin{array}{l}103 \pm 33 \\
102 \pm 33 \\
113 \pm 45\end{array}$ & $\begin{array}{l}83 \pm 33 \\
93 \pm 40 \\
96 \pm 40\end{array}$ & $\begin{array}{l}79 \pm 27 \\
92 \pm 38 \\
88 \pm 35\end{array}$ \\
\hline
\end{tabular}

The mean blood sugar values after the eight-hour fast are significantly greater than those after the 12-hour fast at fasting 